\title{
ICSSC Guidance on Implementing Executive Order 12941 on Seismic Safety of Existing Federally Owned or Leased Buildings
}

Diana Todd and Ann Bieniawski, editors

October 1995

Building and Fire Research Laboratory

National Institute of Standards and Technology

Gaithersburg, MD 20899

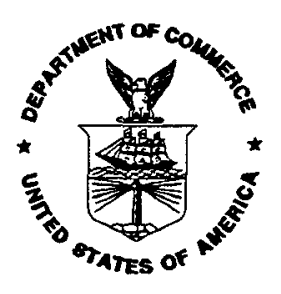

U.S. Department of Commerce

Ronald H. Brown, Secretary

Technology Administration

Mary L. Good, Under Secretary for Technology

National Institute of Standards and Technology

Arati A. Prabhakar, Director
Prepared for:

Federal Emergency

Management Agency

Mitigation Directorate

Washington, DC 20472 


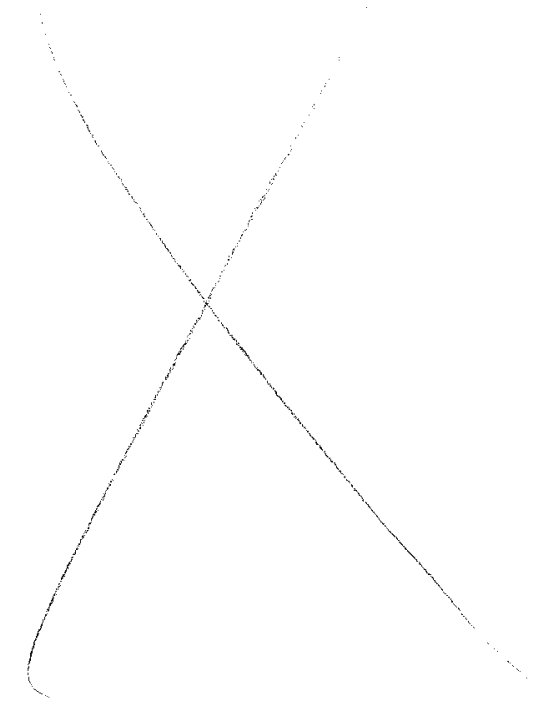




\section{ACKNOWLEDGEMENTS}

The Interagency Committee on Seismic Safety in Construction (ICSSC) Subcommittee 1, Standards for New and Existing Buildings, developed this document for formal ballot review and approval by the full ICSSC. The following people contributed to the development of this document:

ICSSC Members:

H.S. Lew, chairman

Kharaiti Abrol

Charles Anderson

Krishna Banga

James Binkley

Jack Brynda

Oilda del Castillo

Harish Chander

Tom Chappell

Joseph Corliss

Richard Cutsinger

Mike Davister

Don Denton

Don Evick

Nathaniel Foster

Joe Galetovic

Charles Gutberlet

Lucian Guthrie

Bruce Hall

Walt Hays

Don Heald

James Hill

Sam Hodges

Larry Hultengren

Bill Jacks

Paul Johnson

Howard Kass

Tom Kearns

Jeff Kimball

Jim Lafrenz

Doreen Christian Laroche

Shi-Chi Liu

Robert Madison

Rita Martin

Tom Moran

Ugo Morelli

Tom Myers

Tom Nelson
National Institute of Standards and Technology

Veterans Affairs

Dept. of Interior

Veterans Affairs

US Postal Service

Dept. of Interior

US Information Agency

Dept. of Energy

US Dept. of Agriculture

Health and Human Services

Tennessee Valley Authority

Dept. of Energy

Dept. of Energy

US Postal Service

Tennessee Valley Authority

Dept. of Interior

US Army Corps of Engineers

US Army Corps of Engineers

General Services Administration

US Geological Survey

US Dept. of Agriculture

Dept. of Energy

US Dept. of Agriculture

Dept. of State

Tennessee Valley Authority

Dept. of Interior

National Aeronautics and Space Administration

Federal Bureau of Prisons

Dept. of Energy

US Air Force

US Dept. of Agriculture

National Science Foundation

Dept. of Transportation

Dept. of Transportation

Environmental Protection Agency

Federal Emergency Management Agency

Smithsonian Institute

Dept. of Energy 
Howard Nickerson

Brian Olson

David Perkins

LJ Porter

Fidel Rodriguez

Eufracio Sabay

Erdal Safak

John Scalzi

Mike Schilling

Herbert Schneider

Subir Sen

Charles Smith

Bob Stein

Lance Swanhorst

Steve Sweeney

Terry Wong

Marshall Wright
US Navy

Dept. of Interior

US Geological Survey

Dept. of Interior

US Army Corps of Engineers

Dept. of Interior

US Geological Survey

National Science Foundation

Dept. of State

Dept. of Interior

Dept. of Energy

Dept. of Interior

Dept. of Transportation

Environmental Protection Agency

US Army Corps of Engineers

Dept. of Interior

Dept. of Interior

ICSSC Technical Secretariat:

Diana Todd, NIST

Ann Bieniawski, NIST

Structural Engineering Consultants:

Chris Poland, Degenkolb Engineers

William T. Holmes, Rutherford \& Chekene

NIST Consultants

Keith Eberhardt, Engineering Statistics

Terry King, Computer Databases 


\section{PREFACE}

On December 1, 1994, the President signed Executive Order 12941, Seismic Safety of Existing Federally Owned or Leased Buildings. The order adopted minimum technical standards for all future seismic safety evaluation and rehabilitation projects for Federally owned and leased buildings. These standards, Standards of Seismic Safety for Existing Federally Owned or Leased Buildings, are referred to in this document as ICSSC RP4. In addition, the order called for all agencies and departments owning or leasing buildings to develop, by December 1, 1998, a seismic inventory of their owned and leased buildings, and to estimate the costs of mitigating unacceptable seismic risks in that inventory.

The inventory and cost information is being collected in order to develop reliable information upon which to build future public policy. At the time the order was signed, only limited data on the vulnerability of the approximately half-million Federally-owned buildings existed. The government-wide seismic rehabilitation cost estimates that could be generated based on this data were judged to be too uncertain to allow for reliable budget planning.

The order directs the Interagency Committee on Seismic Safety in Construction (ICSSC) to issue guidance on how to develop the inventory and cost estimate. Thirty Federal departments and agencies with an interest in seismic safety participate in the ICSSC. A major role of the ICSSC is to encourage the adoption of consistent and effective seismic safety practices by all entities of the Executive Branch of the Federal government. This is accomplished in part by developing and issuing Recommended Practices. A Recommended Practice (ICSSC RP document) must be approved by at least two thirds of the member departments and agencies before it is issued.

This document, ICSSC RP5, presents the inventorying and cost estimating guidance called for in Executive Order 12941. A supplemental document, How-To Suggestions for Implementing Executive Order 12941 on Seismic Safety of Existing Federal Buildings, A Handbook, to be published in December 1995, gives examples of how to put this guidance into practice.

Each agency's inventory and cost estimate is to be forwarded to the Federal Emergency Management Agency (FEMA) by December 1, 1998. FEMA will use the data to examine the costs and benefits of a wide variety of potential programs to upgrade the seismic safety of existing Federal buildings. The order directs FEMA to submit to Congress, by December 1, 2000 , a "comprehensive report on how to achieve an adequate level of seismic safety in federally owned and leased buildings in an economically feasible manner." It is hoped that this effort will lead to the adoption of a pro-active program of systematic upgrading of the seismic safety of Federal buildings.

The Technical Secretariat of the ICSSC is maintained by the Building and Fire Research Laboratory at the National Institute of Standards and Technology (NIST). The Technical Secretariat publishes and distributes ICSSC publications. For additional copies of this or other ICSSC documents, write to:

ICSSC Technical Secretariat

NIST/Building and Fire Research Laboratory

Building 226, Room B158

Gaithersburg, MD 20899 


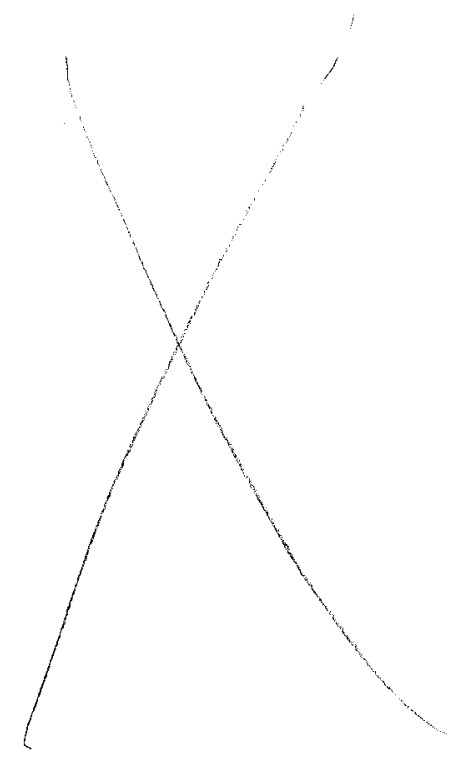




\begin{abstract}
In this guidance document, the Interagency Committee on Seismic Safety in Construction (ICSSC) recommends appropriate approaches for Federal departments and agencies to use in implementing the inventorying and cost estimating requirements of Executive Order 12941. The inventories and cost estimates are to be submitted to FEMA by December 1, 1998. The ICSSC recommends that all Federally-owned buildings be included in an electronic inventory database of specified format. Buildings are to be identified as either exempt or non-exempt from the seismic standards adopted by the order. All exceptionally high risk buildings are to be seismically evaluated, and estimates of the cost of their rehabilitation developed. Additionally, agencies are to perform seismic evaluations on a representative sample of their non-high-risk, non-exempt buildings, and use this information to estimate the vulnerability of that population and the cost of achieving adequate seismic safety.
\end{abstract}




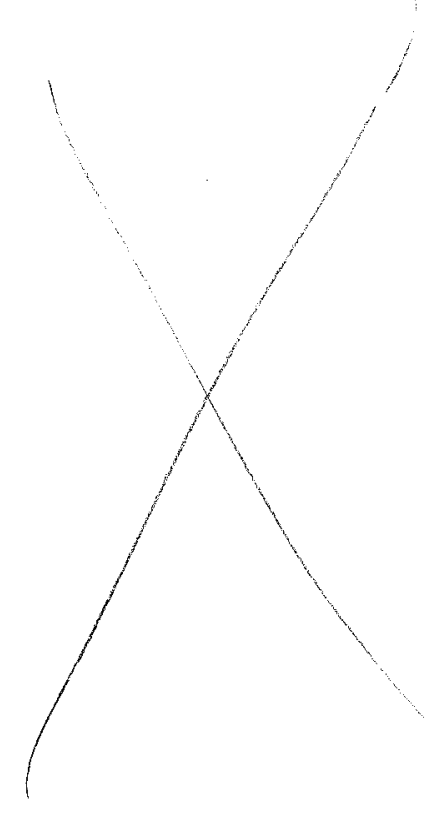




\section{TABLE OF CONTENTS}

ACKNOWLEDGEMENTS $\ldots \ldots \ldots \ldots \ldots \ldots \ldots \ldots \ldots \ldots$ i

PREFACE $\ldots \ldots \ldots \ldots \ldots \ldots \ldots \ldots \ldots \ldots \ldots \ldots \ldots \ldots \ldots \ldots \ldots \ldots$

ABSTRACT $\ldots \ldots \ldots \ldots \ldots \ldots \ldots \ldots \ldots \ldots \ldots \ldots \ldots$

1.0 GOAL AND PROCESS $\ldots \ldots \ldots \ldots \ldots \ldots \ldots \ldots \ldots \ldots \ldots$

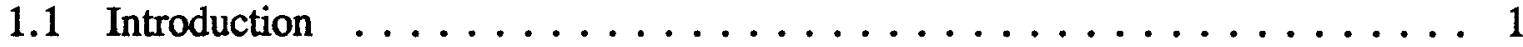

1.2 The Recommended Program: Owned Buildings . . . . . . . . . 1

1.3 The Recommended Program: Leased Buildings . . . . . . . . . . . 2

1.4 Products to be Produced by Each Agency . . . . . . . . . . 2

1.5 Organization of the Guidance . . . . . . . . . . . . . 2

2.0 INVENTORY DATABASE $\ldots \ldots \ldots \ldots \ldots \ldots \ldots \ldots \ldots$

2.1 Relationship to Existing Real Property Inventories . . . . . . . . . 3

2.2 Scope and Screening of Inventory $\ldots \ldots \ldots \ldots \ldots \ldots \ldots \ldots \ldots \ldots$

2.3 Required Inventory Data . . . . . . . . . . . . . . 4

3.0 EVALUATION PLAN $\ldots \ldots \ldots \ldots \ldots \ldots \ldots \ldots \ldots$

3.1 Selection of Buildings for Evaluation . . . . . . . . . . . 9

3.1.1 Evaluate All Exceptionally High Risk Buildings . . . . . . . . . . 9

3.1.2 Evaluate a Representative Sample of Remaining Non-Exempt

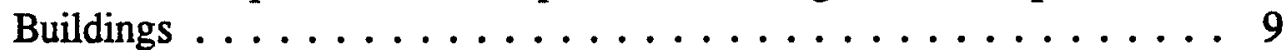

3.1.3 Report Results from Previous Evaluations . . . . . . . . . 10

3.2 Performing Evaluations on Selected Buildings . . . . . . . . . . 10

3.2 .1 Goal of Evaluation . . . . . . . . . . . . . . 11

3.2.2 DNR (Definitely Needing Rehabilitation) Buildings . . . . . . . 11

4.0 ESTIMATING COST OF REHABILITATION . . . . . . . . . . . . 13

4.1 Cost Estimates for Evaluated and Deficient Buildings . . . . . . . 13

4.2 Cost Estimates for Non-Evaluated Buildings . . . . . . . . . . . . 13

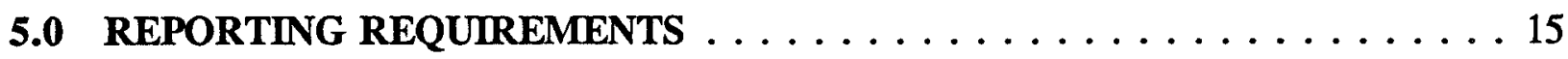

The reporting requirements are as follows.

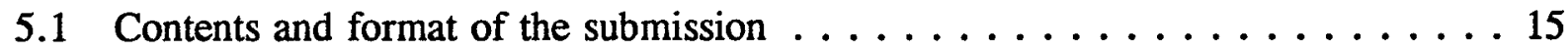

5.1 .1 Databases ......................... 15

5.1 .2 Supporting written documentation $\ldots \ldots \ldots \ldots \ldots \ldots$

5.2 Corrections to Submitted Databases . . . . . . . . . . . 16

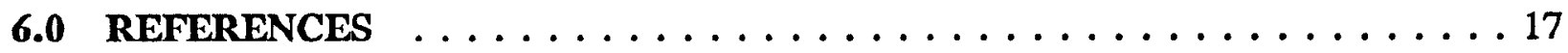

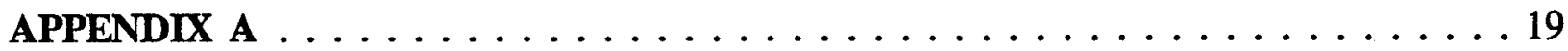




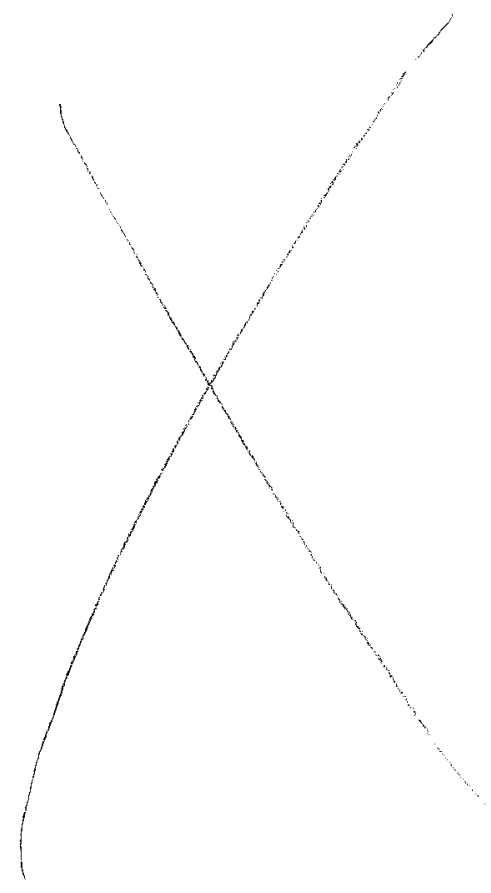

viii 


\section{ICSSC Guidance on Implementing Executive Order 12941 on Seismic Safety of Existing Federally Owned or Leased Buildings}

\subsection{GOAL AND PROCESS}

\subsection{Introduction}

On December 1, 1994, President Clinton signed Executive Order 12941, Seismic Safety of Existing Federally Owned or Leased Buildings. (See Appendix A for a copy of the order). Executive Order 12941 is but one step in a longer term effort to meet one of the goals established by Congress and the President in creating the National Earthquake Hazard Reduction Program (NEHRP) and reaffirmed in the reauthorization of that program in November 1990 by Public Law 101-614: to reduce seismic risk in Federal buildings to acceptable levels in a systematic way. Questions remain about how much it will cost, how long it will take, and what the top priorities should be in any program developed to achieve this goal.

Section 2 of the order is designed to collect the information needed to resolve some of the outstanding questions. Section 2 requires that all agencies and departments inventory their owned and leased buildings and estimate the costs of achieving adequate seismic safety in those buildings. The results of the cost estimate, along with supporting documentation, are to be submitted to the Director of the Federal Emergency Management Agency (FEMA) no later than four years after the signing of the order. Within six years of the signing of the order, or on or before December 1, 2000, FEMA is required to submit to Congress "a comprehensive report on how to achieve an adequate level of seismic safety in federally owned and leased buildings in an economically feasible manner." The report is to be developed in consultation with the Interagency Committee on Seismic Safety in Construction (ICSSC), making use of the inventory data and cost estimates submitted by building-owning and -leasing agencies.

Section 2 of the order also requires the ICSSC, within one year, to provide guidance on implementing certain portions of the Executive Order. This document provides that guidance. Detailed information on implementing the guidance in this document is included in a companion document to be published in December 1995, How-To Suggestions for Implementing Executive Order 12941 on Seismic Safety of Existing Federal Buildings, A Handbook [Bieniawski, publication pending], herein called the Handbook.

\subsection{The Recommended Program: Owned Buildings}

The collected information will be used to examine a wide variety of possible Federal seismic rehabilitation programs. Given the anticipated public-policy and budgetary implications of any recommended rehabilitation program, it is vital that the data upon which the recommendation is based be of high quality: reliable, accurate, and defensible. However, given that the Federal government owns close to a half million buildings, it would be prohibitively costly to collect detailed seismic vulnerability information and rehabilitation cost estimates on the entire population. The ICSSC therefore recommends that data based on seismic evaluations be collected on all high risk/high priority buildings and on a representative sample of lower 
risk/lower priority buildings, as determined by the agency in both cases.

\subsection{The Recommended Program: Leased Buildings}

The Executive Order requires that agencies inventory their leased buildings as well as owned buildings, and to develop estimates of the cost of mitigating unacceptable risks. The seismic safety standards adopted by the order, ICSSC RP4 [ICSSC 1994], include a program for reducing the seismic risk in leased buildings. Under this program, existing leases may be held without action until they expire, but no new leases or lease renewals can be made in seismically unacceptable space. This program is expected to reduce the unacceptable seismic risk in leased buildings in a systematic, low cost way. The ICSSC does not expect that a more pro-active program will be recommended for leased buildings any time in the foreseeable future.

Therefore, the ICSSC recommends that for compliance with the Executive Order 12941 requirement for an inventory of leased buildings, agencies submit the leased building inventory that is prepared annually by the agency at the request of the General Services Administration to fulfill real property reporting requirements, or any current agency leased-property inventory. No additions or modifications of this database are deemed necessary. For compliance with the Executive Order requirement for a cost estimate for reducing unacceptable risks in leased buildings, agencies are asked to estimate the cost impact of the ICSSC RP4 program for reducing risk in leased buildings and to report that cost in the supporting documentation that is submitted to FEMA. If an agency plans to use a different approach to reducing risk in leased buildings, that program and an estimate of the costs of implementing the program should be described in the supporting documentation submitted to FEMA. Further guidance on this topic is included in the Handbook.

\subsection{Products to be Produced by Each Agency}

The order requires each agency owning or leasing buildings to complete its inventory and cost estimate, and submit the cost estimate and supporting documentation to the Director of FEMA by December 1, 1998. The ICSSC recommends that each agency submit two electronic databases, one for owned buildings and another for leased buildings, and a written report with supporting documentation. Details on the content, development, and reporting format of the databases and supporting documentation are included in this document and in the Handbook.

\subsection{Organization of the Guidance}

Section 2 of this document describes the seismic inventory database to be created for all owned buildings. Section 3 presents recommendations for selecting buildings for seismic evaluation. Technical guidance covering the actual engineering evaluation is included in ICSSC RP4. The evaluations are to be used to determine the acceptability or unacceptability of seismic safety in selected owned buildings. Section 4 describes recommended cost estimating procedures to be used with buildings found to pose an unacceptable seismic risk. It also addresses estimating the cost of achieving acceptable seismic safety in those buildings which have not been evaluated. Section 5 outlines the reporting procedures to be used. More detailed descriptions of each recommendation, and suggested procedures for carrying out inventorying and cost estimating tasks can be found in the related sections in the Handbook. 


\subsection{INVENTORY DATABASE}

The Interagency Committee on Seismic Safety in Construction (ICSSC) recommendation for creating the owned-building inventory called for in the Executive Order is as follows.

\subsection{Relationship to Existing Real Property Inventories}

Most agencies annually submit an inventory of real property to the General Services Administration (GSA). This Executive Order 12941 inventory guidance tries, as much as possible, to use the same data that is collected by agencies to meet GSA inventory requirements, to minimize duplication of effort and maximize consistency of reporting across various government inventory projects. However, the seismic inventory called for by Executive Order 12941 will require the collection of some types of information that are not included in the GSA inventory. Agencies need not add this information to the GSA-required report. The inventory to be submitted to the Federal Emergency Management Agency (FEMA) is to be in the form of an electronic database, using a generic electronic format. It will make use of data that may have been collected already by agencies to fulfill GSA requirements, but it will not require modification of annual reporting to GSA.

\subsection{Scope and Screening of Inventory}

All owned buildings are to be included in the inventory database. Each building will be classified as either exempt or non-exempt.

Exempt Buildings are those which meet the criteria for exemption given in Section 1.3 in ICSSC RP4, reprinted below. The seismic risk in these buildings is expected to be very low, such that seismic rehabilitation would not be necessary. Additionally, buildings may be exempted if they will no longer be used by any branch of the Federal government in five years, because they are scheduled to be abandoned, demolished, sold, or otherwise removed from government service.

Non-Exempt Buildings are those which do not meet the criteria for exemption. The level of seismic risk in these buildings is not immediately apparent; the fact that they are not eligible for exemption means that they cannot be readily identified as presenting very low risk.

In this guidance document, the process through which exempt buildings are identified is known as "screening". Detailed suggestions for screening methods are given in the Handbook. ICSSC RP4 exemptions are as follows:

a. buildings classified for agricultural use, or intended only for incidental human occupancy, or occupied by persons for a total of less than 2 hours a day,

b. detached one- and two-family dwellings that are located in areas having a governing acceleration coefficient less than 0.15 (within the United States, where $A_{v}$ is less than 0.15 as delineated on Map 4 of the 1991 NEHRP Recommended Provisions for the Development of Seismic Regulations for New Buildings), (note: Map 4 is identical in the 1991 and 1994 editions of the NEHRP Recommended Provisions) 
c. special structures including, but not limited to: bridges, transmission towers, industrial towers and equipment, piers and wharves, and hydraulic structures,

d. one-story buildings of steel light frame or wood construction with areas less than $280 \mathrm{~m}^{2}$ (3000 square feet),

e. fully-rehabilitated buildings which comply with the ICSSC RP4 seismic safety standards in all four compliance categories (structural, nonstructural, geologic/site hazards, and adjacency),

f. post-benchmark buildings as defined in Table 1 of ICSSC RP4 which also comply with the nonstructural, geologic/site, and adjacency compliance categories,

g. pre-benchmark buildings which have been shown by evaluation to be life-safe in all four compliance categories,

h. buildings constructed for the Federal government whose detailed design was done after the date of the adoption of Executive Order 12699 (January 5, 1990) and that were designed and constructed in accordance with the ICSSC Guidelines and Procedures for Implementation of the Executive Order on Seismic Safety of New Building Construction [ICSSC 1992],

i. leased buildings identified in Section 1.3.2 (of ICSSC RP4) as exempt, or

j. Federally permitted or regulated privately owned buildings on Federal land.

Agencies which elect to specify benchmark years for exemption which differ from those given in ICSSC RP4 shall report the years selected and rationale for the decision in the supporting documentation. (See the Handbook for detailed guidance on identifying exempt buildings.)

For exempt buildings, only a minimal amount of information need be collected and reported. (See Section 2.3 and Table A.) Additional information must be collected for non-exempt buildings.

\subsection{Required Inventory Data}

Each building in the electronic inventory database will fall into one of the following three categories: 1) exempt, 2) non-exempt, not evaluated, and 3) non-exempt, evaluated. The types of data to be reported for each of the three categories of buildings are given below and in Table A. Definition of terms used follows the lists of data categories.

For exempt buildings, the inventory data is to include:

- a unique identifier

- location by state and county

- seismicity: high, moderate or low

- total area in square meters

- reason for exemption

For non-exempt, not evaluated buildings, the inventory data is to include:

- all types of data required for exempt buildings (the reason for exemption should be reported as "not exempt")

- occupancy class

- whether building is essential

- whether building is historic 
- date of construction

- model building type

- number of stories

For non-exempt, evaluated buildings, the inventory data is to include:

- all types of data required for non-exempt, not evaluated buildings

- whether building is perceived to be exceptionally high risk

- evaluation procedure used

- soil type

- foundation type

- outcome of the evaluation: OK or deficient

- if deficient, why deficient,

- if deficient, estimate of the cost of rehabilitation

- if deficient, source of cost estimate

Terms used above and in Table $\mathrm{A}$ which require definition are as follows. More detailed information on each of the data categories, including codes to be used in reporting the information, are given in the Handbook.

Unique Identifier is whatever alpha-numeric designation the agency uses to track its buildings in its own real property inventory. It may be an address, a coded number, or some other method of identifying a specific building in the database.

Seismicity levels are defined by the Map Areas given on Map 2 ( $A_{v}$, county-by-county) in the 1994 NEHRP Recommended Provisions [BSSC, 1995]. (The Handbook provides a table indicating seismicity levels by state and county. The Handbook also gives guidance on using the contour maps from the NEHRP Recommended Provisions for determining seismicity level, for those agencies that wish to make more fine distinctions than are possible using a county-based map.) Seismicity must be reported for all buildings, exempt and non-exempt.

$\begin{array}{ll}\text { Low seismicity } & \text { Map Areas 1 \& } 2 \\ \text { Moderate seismicity } & \text { Map Areas 3 \& 4 } \\ \text { High seismicity } & \text { Map Areas 5, 6, \& } 7\end{array}$

Occupancy Classes are to be the same as those used in creating the real-property inventory for annual submission to GSA. Occupancy class is to be reported for all non-exempt buildings. The 12 occupancy classes are:

- offices

- hospitals

- prisons

- schools

- post offices

- other institutions
- housing

- storage

- industrial

- service

- research \& development

- miscellaneous

GSA does not provide standard definitions for these occupancy classes. For purposes of consistency, agencies are urged to use the same definitions for this seismic inventory database as their agency uses for the GSA inventory, i.e. a building that is reported as 
"service" in the GSA inventory should also be reported as "service" in the seismic inventory database.

Essential buildings are those which, in the judgement of the owning agency, require a level of seismic resistance that is higher than life safety. (Life safety is the minimum level of protection required by ICSSC RP4. After an earthquake, an ICSSC RP4 "life-safe" building should not have caused any fatalities, but it may be so badly damaged that it is no longer functional or even salvageable.) Examples of buildings which may fall into the Essential category are:

- hospitals, fire and police stations, communication and command centers and other buildings that must remain functional in order to respond to an earthquake emergency;

- buildings which must remain operational after an earthquake to maintain critical agency functions;

- buildings housing hazardous materials which, if released as a result of an earthquake, would create an unacceptable risk; and

- buildings housing vulnerable populations or extremely valuable contents.

Buildings which do not require greater than life safety protection are to be categorized as Other. The Essential/Other distinction is to be made for all non-exempt buildings.

Historic buildings are those which are included on any local, regional, state, national, or other register of historic buildings. If a building is potentially qualified to be on a historic register, but has not been actually listed, it is not to be deemed historic in this inventory. The Historic/Non-Historic distinction is to be made for all non-exempt buildings.

Model Building Types reported in this inventory are to be the 15 types identified in the FEMA 178 [BSSC, 1992]. The Handbook reproduces the definitions. Model building type is to be reported for all non-exempt buildings.

Soil Types are to be categorized into one of the four soil categories identified in FEMA 178, which are reproduced in the Handbook.

Foundation Types are to be categorized into one of three types: shallow foundations (isolated or continuous spread footings or mats); deep foundations (piles or piers); or other. These types are defined in more detail in the Handbook.

Similar buildings may be reported in the electronic database in groups, rather than as individual entries, if they meet the criteria given below. When buildings are reported in groups, the number of buildings included in the group and the total area in square meters for all buildings in the group must be reported.

Exempt buildings may be reported in groups rather than individually if they have the following characteristics in common:

- same occupancy class

- same state, county and seismicity

- same reason for exemption 
Non-exempt, not evaluated buildings may be reported in groups only if they have the following inventory characteristics in common:

- all characteristics identified above for groups of exempt buildings, except for "reason for exemption"

- $\operatorname{similar}( \pm 10 \%)$ size and number of stories

- similar date of construction ( \pm 5 years)

- same model building type

- same classification in historic, essential, and exceptionally high risk categories

Non-exempt, evaluated buildings may be reported in groups only if they have the following inventory characteristics in common:

- all characteristics identified above for groups of non-exempt, not evaluated buildings

- same soil type

- same foundation type

For groups of buildings sharing these characteristics, a representative building may be selected for evaluation rather than evaluating each building in the group individually. In these cases, the same evaluation outcome, reason for deficiency (if any), and cost per square meter for rehabiliation are to be assumed for all buildings in the group. 
Table A - Required Inventory Data for Owned Buildings

\begin{tabular}{|c|c|c|c|}
\hline Charactenstiv: & Exempt & $\begin{array}{l}\text { Nornexempt? } \\
\text { Evaturt }\end{array}$ & Nor-Erempt \\
\hline Unique Identifier & $\mathrm{x}$ & $\mathbf{X}$ & $\mathrm{X}$ \\
\hline Location - State \& County & $\mathrm{X}$ & $\mathrm{X}$ & $\mathrm{x}$ \\
\hline Seismicity - High, Moderate or Low & $\mathrm{x}$ & $\mathrm{x}$ & $\mathrm{x}$ \\
\hline Area in square meters & $\mathrm{x}$ & $\mathbf{X}$ & $\mathrm{x}$ \\
\hline Reason for exemption, or "not exempt" & $\mathrm{x}$ & $\mathbf{x}$ & $\mathbf{x}$ \\
\hline Occupancy Class (by GSA categories) & & $\mathbf{x}$ & $\mathrm{x}$ \\
\hline Essential or Other & & $\mathrm{x}$ & $\mathrm{X}$ \\
\hline Historic or Non-Historic & & $\mathrm{x}$ & $\mathbf{x}$ \\
\hline Date of construction & & $\mathrm{x}$ & $\mathrm{x}$ \\
\hline Model Building Type & & $\mathbf{X}$ & $\mathbf{x}$ \\
\hline Number of Stories & & $\mathrm{X}$ & $\mathrm{x}$ \\
\hline Exceptionally High Risk or Other & & & $\mathbf{X}$ \\
\hline Evaluation Procedure Used & & & $\mathbf{x}$ \\
\hline Soil Type & & & $\mathbf{x}$ \\
\hline Foundation Type & & & $\mathbf{x}$ \\
\hline Outcome of Evaluation: OK or Deficient & & & $\mathbf{x}$ \\
\hline For Deficient Only: Why Deficient & & & $\mathrm{x}$ \\
\hline For Deficient Only: Estimated Costs of Rehab (4 fields) & & & $\mathrm{x}$ \\
\hline For Deficient Only: Source of Cost Estimate & & & $\mathrm{x}$ \\
\hline
\end{tabular}

NOTE: Each of the characteristics are to be reported in a single field in the electronic database, unless otherwise noted above. Details of reporting (electronic format; number, order and size of fields; codes for categories; etc.) are contained in the Handbook. 


\subsection{EVALUATION PLAN}

The Interagency Committee on Seismic Safety in Construction (ICSSC) recommended plan for selecting buildings for evaluation, and for carrying out those evaluations, is as follows.

\subsection{Selection of Buildings for Evaluation}

\subsubsection{Evaluate All Exceptionally High Risk Buildings}

Standards of Seismic Safety for Existing Federally Owned or Leased Buildings (ICSSC RP4), adopted by the President in Executive Order 12941 for use in Federally owned and leased buildings, identifies several situations in which seismic evaluation and mitigation is required. (See Section 2.1 of ICSSC RP4.) One of these situations is "the building is deemed by the agency to be an exceptionally high risk to occupants or the public at large."

The ICSSC strongly recommends that, as part of performing the inventory required by Executive Order 12941, each department and agency thoroughly examine its building stock and identify those buildings which represent an "exceptionally high risk." Components of risk that should be considered in identifying exceptionally high risk buildings should include not only regional seismicity and structural system, but also building function, number of occupants, value of contents, criticality to mission (whether building is deemed "Essential"), and any other characteristic judged important to the agency. Agencies should define "exceptionally high risk" such that the buildings so identified are those which would be labeled as top priority for seismic rehabilitation. It is expected that the FEMA report to Congress will identify the "exceptionally high risk" buildings as high priority candidates for rehabilitation funding. The Handbook offers suggestions on how to use the data collected for inventory purposes to identify exceptionally high risk buildings.

It is expected that about five to ten percent of each agency's buildings in regions of high seismicity will fall into this category, along with one-half to one percent of the buildings in regions of moderate seismicity, and an extremely small percentage of the buildings in regions of low seismicity. Agencies with higher than average numbers of exemptions can expect to find their numbers of exceptionally high risk buildings to be at the low end of the ranges described above.

Every building identified as posing an exceptionally high risk should be subjected to a seismic evaluation prior to the December 1, 1998 deadline. Results of evaluations performed prior to the signing of Executive Order 12941 need not be repeated, if the original evaluation, in the judgement of the agency, was substantially equivalent to or exceeded the ICSSC RP4 minimum evaluation procedure.

\subsubsection{Evaluate a Representative Sample of Remaining Non-Exempt Buildings}

Of the remaining non-exempt buildings in regions of moderate and high seismicity, agencies are asked to evaluate a representative sample of buildings, considering height, size, occupancy, and model building type. Each agency is to identify specific categories of buildings most representative of its non-exempt population, and perform enough 
evaluations within each category to adequately represent the entire category. It is expected that evaluations of about one to two percent of the non-exempt buildings would provide an adequately representative sample. Specific suggestions on identifying appropriate categories and selecting a representative sample of buildings are included in the Handbook.

\subsubsection{Report Results from Previous Evaluations}

Buildings which were evaluated prior to the initiation of the Executive Order 12941 inventory and cost estimating project (according to criteria substantially equivalent to the ICSSC RP4 minimum evaluation procedure) are considered to have fulfilled the evaluation requirements described in Section 3.2 of this Guidance. Such buildings should be treated as follows:

a. Those buildings which were found to be seismically adequate should be treated as non-exempt buildings with an evaluation outcome of "OK" and reported in the database as described in Section 2.3 of this Guidance. No further action is required on these buildings.

b. Those buildings which were found to be deficient and which were rehabilitated to standards deemed adequate by the agency, are to be categorized as exempt (as per Section 1 of Executive Order 12941) and treated in accordance with Section 2.2 of this Guidance.

c. Those buildings which were found to be deficient but which have not yet been rehabilitated should be treated as non-exempt buildings with an evaluation outcome of "Deficient" and reported in the database as described in Section 2.3 of this Guidance.

Any building previously evaluated to criteria substantially less stringent than the minimum evaluation requirements in ICSSC RP4 cannot be considered as having met the evaluation requirements described in Section 3.2. These buildings should be considered as unevaluated buildings.

Many previously evaluated buildings are likely to be categorized as "exceptionally high risk." Agencies should report the information from those buildings as such. Agencies are encouraged to include previously evaluated buildings which are not "exceptionally high risk" buildings as part of their representative sample of remaining non-exempt buildings in order to utilize available data as much as possible.

\subsection{Performing Evaluations on Selected Buildings}

The minimum evaluation procedure to be used is the preliminary evaluation (checklist procedure) described in ICSSC RP4. The detailed evaluation may be used if the building fails the preliminary checklist in an attempt to more precisely differentiate between the potential hazards identified in the preliminary procedure and true hazards needing rehabilitative action. Agencyspecific evaluation procedures may be used as long as they meet or exceed the procedures in ICSSC RP4. Such procedures are to be summarized in the supporting documentation. 
If the ICSSC RP4 procedure is used, the expected ground acceleration determined from the maps that are cited in ICSSC RP4 shall be considered a minimum allowable value for use in the evaluation. Acceleration values from other sources may be used if they are not lower than the ICSSC RP4 values. However, acceleration values from site specific studies may be used even if they are lower than ICSSC RP4 values.

For buildings requiring higher than life safety performance, each agency should use evaluation criteria and hazard maps deemed most appropriate by agency. The standards and procedures used shall be reported in the accompanying documentation.

\subsubsection{Goal of Evaluation}

For each evaluated building, the goal is to determine and report (in the inventory database) whether the building is OK (provides adequate seismic safety as is) or Deficient (does not provide adequate seismic safety).

For buildings judged Deficient, the cause of the deficiency is also to be noted and reported. Causes of deficiency include:

- structural deficiency

- nonstructural deficiency

- geologic/site hazard is unacceptable

- adjacency problems

- combination of above reasons

- DNR (definitely needing rehabilitation) category (see Section 3.2.2 below)

For buildings judged Deficient, an estimated cost of rehabilitation is to be calculated and reported (see Section 4 of this document).

\subsubsection{DNR (Definitely Needing Rehabilitation) Buildings}

There is no need to perform an engineering evaluation for those buildings selected for evaluation that can be readily identified as definitely needing rehabilitation (DNR) in the opinion of the owning agency. These buildings may be deemed Deficient without further evaluation. An estimated cost of rehabilitation is to be calculated and reported.

Suggested categories of DNR include:

- unreinforced masonry buildings in areas of high seismicity

- concrete frame buildings without shear walls built before 1960 in areas of high seismicity

- pre-cast frame buildings in moderate and high seismic zones

Agencies may identify buildings with certain other characteristics which they deem to be DNR buildings. The rationale used to develop additional agency-specific DNR definitions must be based on documented performance of the structural system, in either laboratory tests or actual earthquakes. Any such definitions must be summarized in the written supporting documentation. 


\subsection{ESTIMATING COST OF REHABILITATION}

The Interagency Committee on Seismic Safety in Construction (ICSSC) recommended procedures for estimating costs of rehabilitation are as follows.

\subsection{Cost Estimates for Evaluated and Deficient Buildings}

For each evaluated building found to be deficient, the following categories of cost are to be calculated and separately reported in the inventory database:

- structural (changes to the lateral force resisting system)

- nonstructural (changes to other parts of the building and to building equipment, systems, and contents)

- finishing (costs of removing and replacing finishes such as wallboard, paint, carpet, etc.)

- project costs (design, testing, and permit fees, cost of project management, etc.)

Costs of other upgrades triggered by the rehabilitation effort (such as handicapped access, asbestos removal, etc.) are not to be included. Details on what is and is not included in each of the cost components are given in the Handbook.

Acceptable cost estimation methods include the following:

a. Have the evaluating engineer develop a preliminary rehabilitation scheme appropriate for the specific structure, not less stringent than the ICSSC RP4 life safety criteria, and calculate the cost of the proposed fix. (Note, for this cost estimation method, the agency may use any nationally accepted seismic hazard map or available site-specific study as the source of ground acceleration values. No specific map is mandated for use.)

b. Use agency-specific cost estimating procedures. Include detailed information on the procedure used in supporting information that is submitted.

c. Use the default method: Follow cost estimating Option II in Second Edition - Typical Costs for Seismic Rehabilitation of Existing Buildings, Volume I [FEMA 156, 1994] to calculate structural costs. Use procedures outlined in Volume II of Second Edition - Typical Costs [FEMA 157, 1995] to calculate nonstructural, finishing, and project costs.

d. If, instead of being rehabilitated, the building would be replaced, a replacement cost should be reported instead of a rehabilitation cost, and so noted.

e. If, instead of being rehabilitated, the building would be abandoned and not replaced, the reported rehabilitation cost should be the cost of disposal. If no disposal cost is anticipated, the rehabilitation cost can be reported as zero.

\subsection{Cost Estimates for Non-Evaluated Buildings}

Agencies are to develop an estimate of the cost of achieving adequate seismic safety for those non-exempt buildings that were not evaluated, where it is expected that rehabilitation will be required. Each of the four sub-categories of cost defined in Section 4.1 are to be developed and reported.

In developing this estimate, agencies should use the vulnerability and cost data collected in non- 
exempt evaluated buildings to estimate the vulnerability and cost for non-exempt non-evaluated buildings. Agencies should address, at a minimum, the following considerations:

a. The proportion of buildings found to be Deficient in the evaluated buildings will likely be greater than the proportion of Deficient buildings in the non-evaluated population. This is because all "exceptionally high risk" buildings should have been identified and evaluated; a significant proportion of these will likely be found Deficient. A rational procedure for estimating the proportion of Deficient buildings in the non-evaluated population, taking this imbalance into account, is to be used and described in the supporting documentation.

b. The proportion of non-evaluated buildings found to be Deficient in regions of low seismicity may be different from proportions in regions of moderate or high seismicity. A rational procedure for accounting for these differences is to be used and reported in the supporting documentation. Differences and similarities in outcomes of evaluations for similar building types in regions of high and moderate seismicity should be examined to identify whether trends can be rationally extrapolated to regions of low seismicity.

c. Existing studies (such as Second Edition - Typical Costs) have shown that rehabilitation costs for essential buildings exceed costs for non-essential buildings. Similarly, rehabilitation costs for historic buildings typically exceed costs for non-historic buildings. Estimated rehabilitation costs for these subcategories of non-evaluated buildings (essential and historic) should be calculated separately from estimates for other building types.

d. Cost estimates for non-evaluated buildings should be based on the 15 model building types (specified in Section 2.3) that represent at least 85 percent of the non-exempt, nonevaluated building stock in regions of moderate and high seismicity.

The cost estimate for rehabilitating the number of Deficient, non-exempt, non-evaluated buildings should be developed and presented in tabular form by three major categories of buildings (Essential, Historic, and All Others), arranged by three areas of seismicity (high, moderate, and low). Further, the All Others category should be arrayed by the 15 model building types that represent at least $85 \%$ of the non-exempt, non-evaluated building stock in regions of high and moderate seismcity for each agency. (See the Handbook for details of appropriate format for reporting.)

The cost estimate should, for each of the building categories prescribed above, indicate both the number of non-evaluated buildings expected to be found Deficient and the expected total area in square meters these buildings represent. Costs in each of the four cost categories, discussed in Section 4.1, are to be reported in both costs per square meter and total cost for the expected population.

A detailed explanation should be provided on the estimating methodology that was employed. Because a building-by-building cost estimate will not be developed for the non-evaluated buildings, the information on cost of rehabilitating Deficient, non-exempt, non-evaluated buildings is to be reported in the supporting documentation, rather than in the inventory database. 


\subsection{REPORTING REQUIREMENTS}

The information collected must be submitted to the Federal Emergency Management Agency (FEMA) no later than Dec. 1, 1998. Earlier submissions will be welcomed. Early submission of portions of the owned building database will be particularly helpful in establishing efficient procedures for transmitting data. Suggested milestones that are appropriate for early submission include:

1. Completion of screening for exempt/non-exempt status.

2. Completion of identification of "exceptionally high risk" buildings.

3. Completion of identification of representative sample of remaining non-exempt buildings.

4. Completion of evaluations.

If early, partial submissions are made, the agency is asked to resubmit the entire database when it is complete (no later than December 1, 1998).

The reporting requirements are as follows.

\subsection{Contents and format of the submission}

The submission shall include two databases in electronic form and supporting written documentation. A detailed format for submissions is given in the Handbook.

\subsubsection{Databases}

Two databases are to be submitted.

1. Database of leased buildings: a duplicate of the agency submission to the General Services Administration (GSA) for real property inventory purposes is acceptable, or any other current agency leased-property database.

2. Database of owned buildings: all owned buildings are to be included. Each building is to be identified as either exempt; non-exempt, not evaluated; or non-exempt, evaluated. See Section 2.3 and Table A for the list of characteristics that must be reported in each of the three categories. The Handbook gives detailed definitions for each of the characteristics, and formatting requirements for the database (number, order and size of fields, codes to be used, etc.)

\subsubsection{Supporting written documentation}

1. Describe any assumptions made during the exemption process; specify benchmark years used.

2. Describe criteria and methodology used to identify "exceptionally high risk" buildings.

3. Describe categories considered and selection procedures used to designate buildings for evaluation in the representative sample of non-exempt buildings.

4. Summarize agency-specific seismic evaluation criteria used for life-safety evaluations if it differs from the ICSSC RP4 minimum procedure.

5. Describe criteria used for evaluation of buildings requiring higher than life safety.

6. Describe any agency-specific DNR (definitely needing rehabilitation) categories used. 
7. Report the cost of performing the evaluations.

8. Describe any agency-specific cost estimating methods used for developing building-by-building cost estimates.

9. Describe methods used for estimating rehabilitation costs for non-evaluated buildings.

10. Report estimated cost of achieving adequate seismic safety in non-evaluated buildings, by Essential, Historic, and All Others categories, the latter arrayed by the 15 building types specified in Section 2.3, by square meter, and in total.

11. Submit an estimated average annual attrition rate (rate at which existing owned buildings are removed from the inventory for any reason).

12. Estimate the cost impact of reducing seismic risk in leased buildings. If a program other than that recommended in ICSSC RP4 (allowing existing leases to expire without action, and not entering into new leases in inadequate space) will be used, describe the program.

\subsection{Corrections to Submitted Databases}

Agencies will be asked to correct and re-submit entire databases or individual database entries that are not consistent with the prescribed reporting format, as described in the Handbook, or that present unintelligible data. 


\subsection{REFERENCES}

Bieniawski, A. and D. Todd, How-To Suggestions for Implementing Executive Order 12941 on Seismic Safety of Existing Federal Buildings, A Handbook, (under preparation, publication expected December 1995), National Institute of Standards and Technology, Gaithersburg, MD.

Building Seismic Safety Council (1995). NEHRP Recommended Provisions for the Development of Seismic Regulations for New Buildings, Provisions and Commentary, 1994 edition, FEMA 222A \& 223A, Federal Emergency Management Agency, Washington, DC, 1995.

Building Seismic Safety Council (1992), NEHRP Recommended Provisions for the Development of Seismic Regulations for New Buildings, Provisions and Commentary, 1991 edition, FEMA 222 \& 223, Federal Emergency Management Agency, Washington, DC, 1992.

Building Seismic Safety Council (1992). NEHRP Handbook for the Seismic Evaluation of Existing Buildings, FEMA 178, Federal Emergency Management Agency, Washington, DC, 1992.

Federal Emergency Management Agency (1994). Second Edition Typical Costs for Seismic Rehabilitation of Existing Buildings, Volume 1 - Summary, FEMA 156, December, 1994.

Federal Emergency Management Agency (1995). Second Edition Typical Costs for Seismic Rehabilitation of Existing Buildings, Volume II - Supporting Documentation, FEMA 157, October, 1995.

Interagency Committee on Seismic Safety in Construction (1994). Standards of Seismic Safety for Existing Federally Owned or Leased Buildings, NISTIR 5382. Report developed by the Interagency Committee on Seismic Safety in Construction, Recommended Practice 4, ICSSC RP4, D. Todd, editor. National Institute of Standards and Technology, Gaithersburg, MD, February, 1994.

Interagency Committee on Seismic Safety in Construction (1992). Guidelines and Procedures for Implementation of the Executive Order on Seismic Safety of New Building Construction, NISTIR 4852. Report developed by the Interagency Committee on Seismic Safety in Construction, Recommended Practice 2.1-a, ICSSC RP2.1-A, D. Todd and A. Bieniawski, editors, National Institute of Standards and Technology, Gaithersburg, MD, 1992.

Public Law 101-614, The National Earthquake Hazards Reduction Program (NEHRP) Reauthorization Act of 1990, 104 STAT. 3231, November, 1990. 


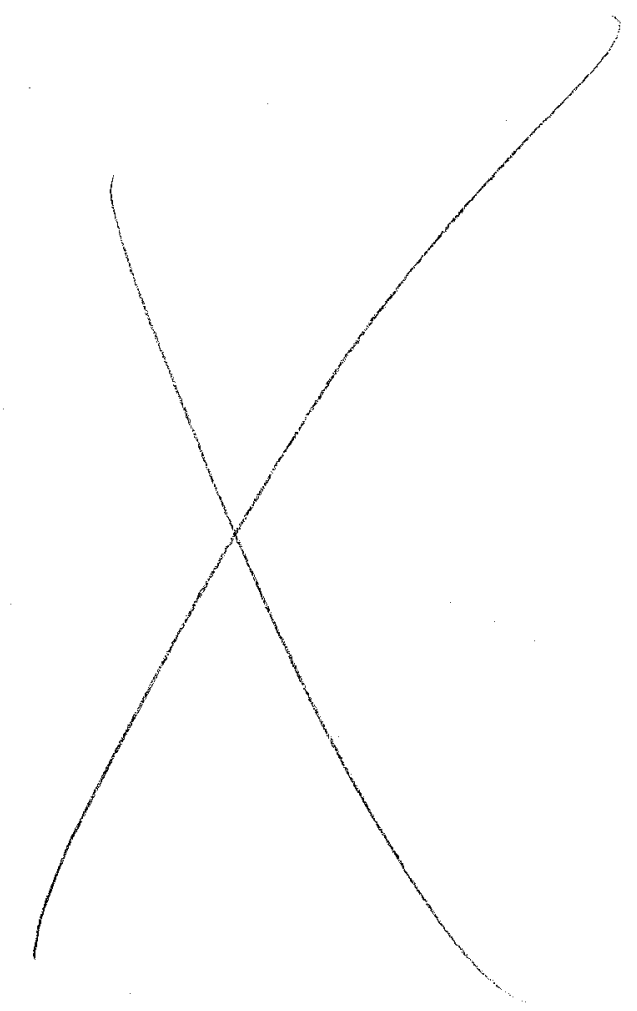


APPENDIX A

Text of Executive Order 12941 


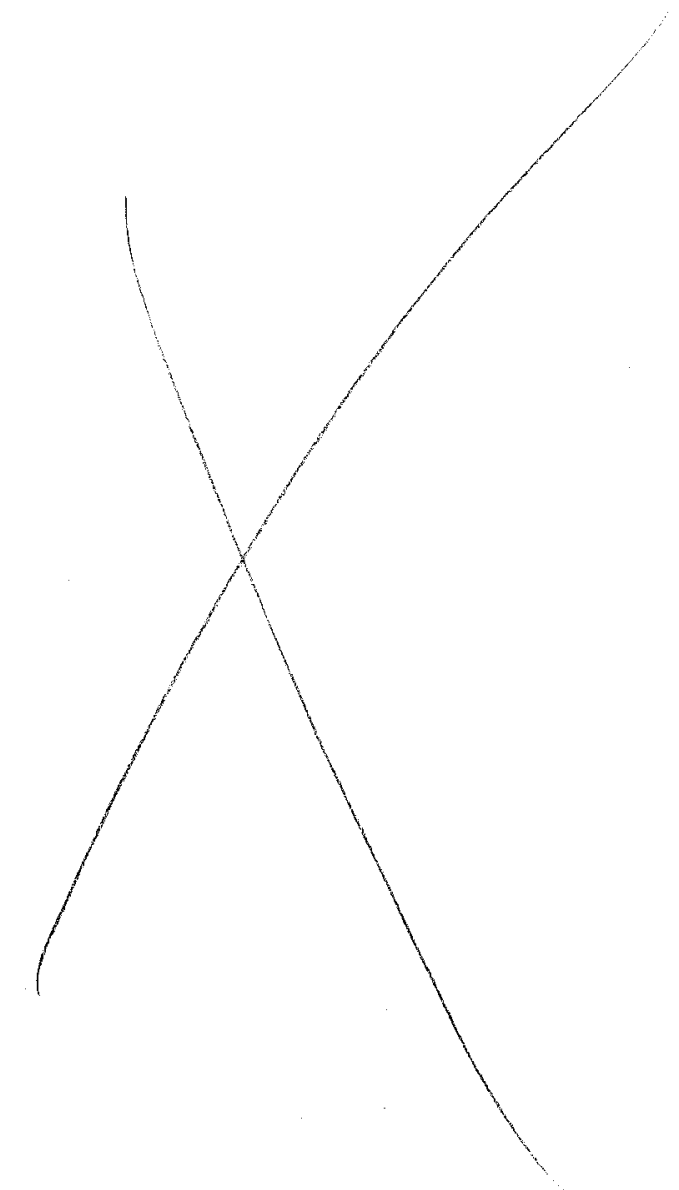


Federal Register

Vol. 59, No. 232

Monday, December 5, 1994

\section{Presidential Documents}

Title 3-

The President
Executive Order 12941 of December 1, 1994

\section{Seismic Safety of Existing Federally Owned or Leased Build- ings}

By the authority vested in me as President by the Constitution and the laws of the I'nited States of America, and in furtherance of the Earthquake Hazards Reduction Act of 1977, as amended by Public Law 101-614, which requires the President to adopt "standards for assessing and enhancing the seismic safety of existing buildings constructed for or leased by the Federal Government which were designed and constructed without adequate seismic design and construction standerds" (42 U.S.C. 7705 b(a)), it is hereby ordered as iollows:

Section 1. Adoption of Minimum Standards. The Standards of Seismic Safety for Existing Federally Owned or Leased Buildings (Standards), developed, issued, and maintained by the Interagency Committee on Seismic Safety in Construction (ICSSC), are hereby adopted as the minimum level acceptable for use by Federal departments and agencies in assessing the seismic safety of their owned and leased buildings and in mitigating unacceptable seismic risks in those buildings. The Standards shall be applied, at a minimum, to those buildings identified in the Standards as requiring evaluation and, if necessary, mitigation. Evaluations and mitigations that were completed prior to the date of this order under agency programs that were based on standards deemed adequate and appropriate by the individual agency need not be reconsidered unless otherwise stipulated by the Standards.

For the purposes of this order, buildings are defined as any structure, fully or partially enclosed, located within the United States as defined in the Earthquake Hazards Reduction Act of 1977, as amended, (42 U.S.C. 7703(5)), used or intended for sheltering persons or property, except for the exclusions specified in the Standards.

Sec. 2. Estimating Costs of Mitigation. Each agency that owns or leases buildings for Federal use shall, within 4 years of the issuance of this order, develop an inventory of their owned and leased buildings and shall estimate the costs of mitigating unacceptable seismic risks in those buildings. The cost estimate shall be based on the exemptions and evaluation and mitigation requirements ir: the Standards. Guidance for the development of the inventory and cost estimates will be issued by the ICSSC no later than 1 year after the signing of this order. Cost estimates with supporting documentation shall be submitted to the Director of the Federal Emergency Management Agency (FEMA) no later than 4 years after the signing of this order.

Sec. 3. Implementation Responsibilities. (a) The Federal Emergency Management Agency is responsible for (1) notifying all Federal departments and agencies of the existence and content of this order; (2) preparing for the Congress, in consultation with the ICSSC, no later than 6 years after the issuance of this order, a comprehensive report on how to achieve an adequate level of seismic safety in federally owned and leased buildings in an economically feasible manner; and (3) preparing for the Congress on a biennial basis, a report on the execution of this order.

(b) The National Institute of Standards and Technology is responsible for providing technical assistance to the Federal departments and agencies in the implementation of this orcior.

(c) Federal departments and agencies may zequest an exemption from this order from the Director of the Office of Management and Burget. 
IFR Doe $94-30035$

Fi!ec 12-2-94: 9:26 an!

Piiling code 3195-01-1)
Sec. 4. Updating Programs. The ICSSC shall update the Standards at least every 5 years. It shall also update the Standards within 2 years of the publication of the first edition Oi FEMA's Guidelines for Seismic Rehabilitation of Buildings and Commentory.

Sec. 5. Judicial Revien: Nothing in this order is intended to create any right to administrative or tjudicial seview, or any other right, benefit, :or trust resfonsibility, substantive or procedural, enforceable at law by any party against :the United States, its ragencies "or instrumentalities, wits rofficers or employees, or any person.

\section{vivious Jevinten}

THE WHTTE HOUSE.

December 1. 1994. 